Aneta Dimitrova (Sofia)

\title{
Translation AND Transformation OF JOHN CHRYSOSTOM'S URBAN IMAGERY into Old Church Slavonic
}

St John Chrysostom preached for 20 years in the two major cities of the Eastern Roman empire - Antioch (386-397) and Constantinople (398-404). He delivered hundreds of sermons, some of these were written down at the time of preaching, others were edited and published later. More than 800 are considered genuine, another thousand texts bear his name as the author ${ }^{1}$. His works were widely popular in all the neighbouring cultures from the $5^{\text {th }}$ century onwards. In the $9^{\text {th }}$ century, the Slavonic tradition joined this trend.

The title of my present research suggests mainly a survey on literary and cultural reception, but it also allows a discussion on several broader questions, such as the history of rhetoric and preaching, the use of literary sources as historical evidence, late antique and medieval architecture, city planning, and everyday life. John Chrysostom's extensive and diverse body of work provides a large number of examples and theoretical models in various study domains. Here I will focus on his depictions of the city and urban life and their rendition in the early Slavonic tradition.

John Chrysostom was a preacher and a writer - many of his sermons were both oral performances in an actual reality, and written works meant for reading in posterity, outside of their immediate context. His fellow-citizens in Antioch and Constantinople were his audience, but they were also subjects of his sermons. He drew material from contemporary events, natural disasters, political and social turmoil, local landmarks, the neighbourhood, etc. It is not surprising then, that his works served as documental sources in academic research. The written texts, which have come down to us in numerous manuscripts, still keep traces of direct communication $^{2}$. The preacher addresses his audience from time to time, points

${ }^{1} \mathrm{~S}$. VoIcu, Une nomenclature pour les anonymes du corpus pseudo-chrysostomien, B 51, 1981, p. 297-305.

${ }^{2}$ Some aspects of this question are discussed also by other researchers, Preacher and Audience. Studies in Early Christian and Byzantine Homiletics, ed. P. Allen, M. Cunningham, Leiden 1998, p. 18: 
to the surroundings, refers to the previous day ("yesterday"), names particular persons, and local suburbs. One way of looking at his preaching, as Wendy Mayer points out, is as a liturgical act which takes place within a liturgical setting ${ }^{3}$. In this line of reasoning, Mayer poses a number of questions concerning the actual moment of delivery and the interaction between the preacher and his congregation, such as: "What behaviour does he expect of the audience during the homily", "Where is his audience situated?", "Can John project his voice adequately?", "Who is sitting and who is standing?", and so on ${ }^{4}$. Another strain of questions refers to the preacher's surroundings: "In which city are John and the audience in question situated?", "In what part of the urban or suburban landscape are they positioned?", "In which building are they located?", etc. ${ }^{5}$ None of these questions, which represent the liturgical, topographical, social, or personal perspective on Chrysostom's preaching, is relevant to the afterlife of his homilies. Later copies and translations take the homily away from the initial moment of delivery and bring it to a new readership (or audience), into another era and another cultural and topographical context. This loss of actuality is typical for all oral sermons put into writing ${ }^{6}$. The double nature of the homily - oral and written - creates an artificial, rhetorical reality, cf. W. Mayer again:

Even if we can confirm that the homily that survives was delivered before a live audience and is identical to the original, and we can demonstrate that John individualised the content in response to his audience, we must still deal with the fact that the information itself is presented within a rhetorical medium and represents a constructed reality ${ }^{7}$.

Some elements of the live delivery, such as improvised dialogues with the audience, exempla, deictic expressions and other references to the context, are often preserved in written sermons. However, they are not only remnants from a single past event, but also rhetorical devices aimed at attaining more convincing moral and instructive power ${ }^{8}$. The homily - be it exegetical, panegyrical, polemical or

Homilies which were preached ex tempore obviously represent the best sources for this type of information; those which were prepared beforehand or edited after the event rarely indicate the dynamics of a particular occasion.

${ }^{3}$ W. Mayer, John Chrysostom: Extraordinary Preacher, Ordinary Audience, [in:] Preacher and Audience..., p. 115.

${ }^{4}$ Ibidem, p. $115-116$.

${ }^{5}$ Ibidem, p. 126. W. Mayer gives a detailed account on the geographical, topographical, urban and architectural data in Chrysostom's homilies, ibidem, p. 126-129; see also W. MAYER, The Homilies of St John Chrysostom. Provenance. Reshaping the Foundations, Rome 2005, p. 289-302.

${ }^{6}$ The medieval sermon both as oral and literary genre in the Western tradition is examined in: The Sermon, ed. B.M. KIENZLE, Turnhout 2000, esp. p. 159-174; the signs of orality in written sermons and the tension between the written text and the oral discourse are summarized on p. 965-978. The volume gives also an extensive bibliography on general and specific questions.

${ }^{7}$ W. MAYer, John Chrysostom: Extraordinary Preacher..., p. 108.

${ }^{8}$ See, e.g. Preacher and Audience..., p. 13: By employing an informal and conversational method of discourse, frequently inventing imaginary interlocutors, preachers may be inventing a dialogue which did 
ethical - is a rhetorical genre and John Chrysostom is famously one of its best champions. His eloquence, acquired through classical education, applies some methods of the second sophistic in Christian context ${ }^{9}$. He uses metaphors, comparisons, ecphraseis and other vivid figures of speech in a wide range of topics. For instance, he borrows images from athletic games, medicine, sea and navigation, the hyppodrome, the theater, etc. - sources typical for the sophists ${ }^{10}$, but always directed by the preacher at moral or religious instruction.

John Chrysostom's urban imagery also falls into these two categories. On the one hand, his descriptions of the cityscape and the urban life give a snapshot of the era and of the actual moment of delivery. On the other hand, they are topo $i$ that transcend the particular space and time and, as written literature, fit into other contexts. By comparing some of these images with their translations into Old Church Slavonic I will try to determine how much of Chrysostom's urban imagery was preserved, what was adapted to the new audience, and what remained unchanged and detached from the actual reality. Some aspects of this cultural transfer were addressed in previous (predominantly lexical) studies on Greek and Roman realia and their rendition in Old Church Slavonic ${ }^{11}$. Terms, names, and places from the classical and late antique world were not entirely unfamiliar to the educated Slavic audience. Personal and geographical names, exotic food, and other objects are frequently mentioned in many genres of translated literature, such as biblical translations, historiography, hagiography, rhetoric, juridical texts, etc. At the same time, the abundant scribal errors suggest that many realia were misunderstood or entirely incomprehensible to the scribes.

not really exist, and again: rhetorical devices such as dialogue and diatribal interjections to the audience, the use of everyday imagery or exempla, and familiar topoi all must have helped to engage an audience which was expecting to some extent to be entertained, ibidem, p. 18.

${ }^{9}$ Cf. T. Ameringer, The Stylistic Influence of the Second Sophistic on the Panegyrical Sermons of St. John Chrysostom. A Study in Greek Rhetoric, Washington 1921 [= PSt, 5]; M.A. BuRns, Saint John Chrysostom's Homilies on the Statues. A Study of Their Rhetorical Qualities and Form, Washington 1930 [= PSt, 22].

${ }^{10}$ Examples from $4^{\text {th }}$ century pagan orators, such as Himerius, Themistius and others, see in T. AMERINGER, The Stylistic Influence..., p. 17-19. Special chapters are dedicated to the praise of a country and of a city in Menander Rhetor, cf. Menander Rhetor, ed. et trans. D.A. Russell, N.G. Wilson, Oxford 1981, p. 28-43, 46-75.

${ }^{11}$ On this topic see e.g. the following research papers and the references therein: A.-M. ТотомАнова, Сведенията за гргко-римския свят в славянския ексиерпт от Хрониката на Юлий

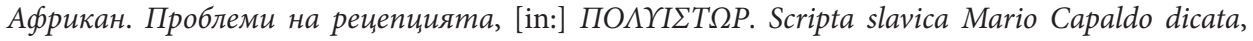
ed. К. Дидди, Москва 2015, p. 316-327; Т. ИлиЕвА, Античната култура през призмата на средновековния български книжовен език, Дзяло, 10, 2017, http://www.abcdar.com/magazine/X/ T.Ilieva_1314-9067_X.pdf [3 IV 2020]; Т. СлАвовА, Византийски реалии в преводаческата практика на старобългарските книжовници, [in:] Laudator temporis acti. Studia in memoriam Ioannis A. Božilov, vol. II, Ius, imperium, potestas litterae ars et archaeologia, ed. I.A. BILIARsKy, Sofia 2018, p. 242-253, and many others. 
The descriptions of the urban life in the late antique city do not always contain specific vocabulary and therefore may remain undetected and unexamined in lexical research. Some of the examples cited below depict scenes set in an urban environment, and the present study investigates not only how specific objects were named but also how ordinary situations were described. The selection of the examples is based on several criteria. The study is focused on genuine Chrysostomian homilies ${ }^{12}$ translated into Old Church Slavonic in the $9^{\text {th }}-10^{\text {th }}$ century. John Chrysostom's authorship is an important criterium, because it gives a reliable point of reference in terms of time and place of origin of the homilies. The translations, however, belong to various anonymous Old Bulgarian translators and are mostly preserved in late manuscripts, some of which are not published ${ }^{13}$. Therefore, the manuscript tradition and the reception in the following centuries should also be kept in mind.

The passages I will discuss below refer to the urban environment, public and private buildings, and the everyday life of the citizens. The examples are excerpted from the following Old Church Slavonic collections and manuscripts: the Chrysorrhoas collection (Zlatostruy) ${ }^{14}$, Chrysostom's On the Statues ${ }^{15}$, Codex Suprasl-

\footnotetext{
${ }^{12}$ Cf. W. Mayer, The Homilies of St John Chrysostom..., p. 26-27; S. Voicu, Pseudo-Giovanni Crisostomo: $i$ confini del corpus, JAC 39, 1996, p. 105-115.

${ }^{13}$ The Greek text of the examples below is cited according to the edition in Patrologia Graeca. The Old Church Slavonic translations are cited according to their respective editions, or according to the earliest accessible manuscripts, if they are unedited.

${ }^{14}$ Translated in the $10^{\text {th }}$ century, its various versions are preserved in $12^{\text {th }}-17^{\text {th }}$ century manuscripts, sеe Я. Милтенов, Златоструй: старобългарски хомилетичен свод, създаден по инициатива на българския иар Симеон. Текстологическо и извороведско изследване, София 2013. The socalled Longer Zlatostruy, which is preserved almost only in Russian manuscripts from $15^{\text {th }}$ century onwards, is unedited. Here it is cited after the earliest complete copy, a Russian manuscript from the Moscow Theological Academy (Russian State Library 173/I, No 43, 1474), cf. Архим. Лвонид, Сведение о славянских рукописях, поступивщих из книгохранилища Свято-Троицкой Сергиевой тавры в библиотеку Троицкой духовной семинарии в 1747 г. (ныне находящихся в библиотеке Московской духовной академии), Вып. 2, Москва 1887, p. 66-68. It is available online http://libfond.ru/lib-rgb/173-i/f-173-i-43/ [11 VII 2020].

${ }^{15}$ De statuis (Ad populum Antiochenum homiliae 1-21), CPG 4330. The scholars are not unanimous about the date and the number of the Old Church Slavonic translations, cf. А.А. Турилов, Андрианты, [in:] Православная энииклопедия, vol. II, Москва 2001, p. 410, http://www.pravenc.ru/ text/115376.html [26 V 2020]; М.С. Мушинская, Адрианты Иоанна Златоуста в южнославянских и русских памятниках, [in:] Лингвистическое источниковедение и история русского языка (2002-2003), Москва 2003, p. 27-74, http://www.ruslang.ru/istochnik_2003 [26 V 2020], especially p. 28 - no data support a complete early Old Church Slavonic (Old Bulgarian) translation, only fragments are extant. But according to D. Bulanin, there was a nearly complete $10^{\text {th }}$-century translation that was revised and preserved in later copies, cf. Д. БулАнин, Текстологические и библиографические арабески. Приложение V. Андрианты в старшем славянском переводе, [in:] Каталог памятников древнерусской письменности XI-XIV вв., Санкт-Петербург 2014, p. 489-510. It is unedited, here it is cited after a $16^{\text {th }}$-century Russian manuscript from the Russian State Library 304/I, No 151 (1597), cf. Иером. ИЛАРИЙ, ИЕРом. АРсенИй, Описание славянских рукописей
} 
iensis $\left(10^{\text {th }} \text { century }\right)^{16}$, and Uspenskij codex $\left(12^{\text {th }} \text { century }\right)^{17}$. Other important Slavonic manuscripts, such as the Symeon florilegium (Izbornik 1073, $11^{\text {th }}$ century), the Troickij codex ( $12^{\text {th }}$ century), the Mihanovic homiliary ( $13^{\text {th }}$ century), and the German codex $\left(14^{\text {th }} \text { century }\right)^{18}$, did not provide any more examples. Although John Chrysostom is the most translated author in the medieval Slavonic literature, one of the reasons for the scarcity of examples is the fact that only selected works and fragments were translated into Slavonic in the early period $\left(9^{\text {th }}-11^{\text {th }}\right.$ century) and the selection was based on their topic and function. As a result, catechetical, festal, and panegyrical homilies in the homiliaries are less likely to contain urban descriptions, compared to the ethical and even exegetical sermons, collected in instructive miscelanies such as Zlatostruy. Some brilliant references of John Chrysostom to the life of his fellow-citizens in Antioch and Constantinople were simply left out of the Slavonic selection. The translations of the later period (from $14^{\text {th }}$ century onwards) are not taken into account, because they represent a different cultural context and principles of translation. Nevertheless, the available instances are sufficient for drawing some conclusions about the way the Slavonic audience saw the $4^{\text {th }}$-century Byzantine city.

\section{City streets and buildings}

The first group of examples describes spacious streets, squares, and buildings. The two biggest cities of the Eastern Roman Empire in the $4^{\text {th }}-5^{\text {th }}$ century were impressive in terms of infrastructure and population even by today's standards. They shared some features, e.g. busy streets and markets, big churches and tall buildings, a hippodrome, noise, nightlife, streetlights, baths, dense and stratified population. Reference to any of these features in Chrysostom's homilies could pertain to either city. Aside from that, Antioch was famous for its porticoed streets, the proximity to the Orontes river and the mountain, and the luxurious suburb Daphne ${ }^{19}$, whereas

библиотеки Свято-Троиикой Сергиевой лавры, Москва 1878, p. 125-128. It is available online http://lib-fond.ru/lib-rgb/304-i/f304i-151/ [11 VII 2020].

${ }^{16}$ Супрасълски или Ретков сборник, vol. I-II, еd. Й. ЗАИмов, М. КАПАлдо, София 1982.

17 Успенский сборник ХІІ-ХІІІ вв., еd. С.И. Котков, Москва 1971.

${ }^{18}$ These manuscripts contain Old Church Slavonic original and translated texts from the $9^{\text {th }}-10^{\text {th }}$ century, including Chrysostomian homilies, cf. Симеонов сборник (по Светославовия препис от 1073 г.), vol. I, Изследвания и текст, София 1991; vol. II, Речник-индекс, София 1993; vol. III, Грбики извори, София 2015; J. Popovsкi, F.J. Thomson, W.R. Veder, The Troickij Sbornik (Cod. Moskva, GBL, F.304 (Troice-Sergieva Lavra) N 12). Text in Transcription, ПК 21-22, 1988; Mihanović Homiliar, ed. R. Aitzetmüller, Graz 1957; Е. МирчевА, Германов сборник от 1358/1359 г. Изследване и издание на текста, София 2006.

${ }^{19}$ For a detailed study on the topography of Antioch in John Chrysostom's works see W. MaYer, The Topography of Antioch Described in the Writings of John Chrysostom, [in:] Les sources de l'histoire du paysage urbain d'Antioche sur l'Oronte. Actes des journées d'études des 20 et 21 septembre 2010. Colloques de l'université Paris 8, ed. C. SAliou, Paris 2012, p. 81-100, with an exhaustive list of topographic data on p. 89-100. 
Constantinople was surrounded on three sides by the sea and was distinguished by the emperial palace and the occasional presence of the emperor ${ }^{20}$.

The following example mentions not only the noise in the (unspecified) city, but also suburbs and houses with golden roofs and triclinia:

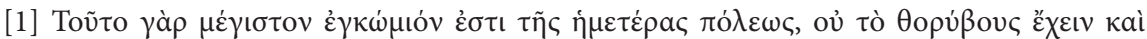

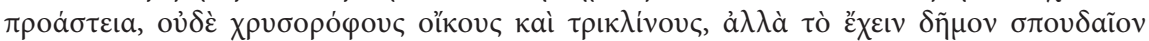

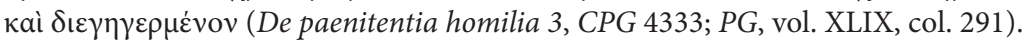

This is the biggest praise to our city, not its noise and suburbs, nor its golden-roofed houses furnished with couches, but its devoted and diligent people.

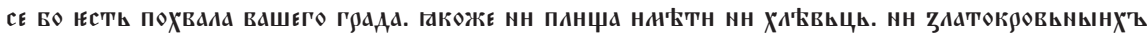

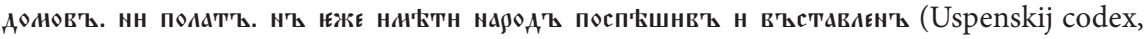
$12^{\text {th }}$ c., f. 180v, ed. С.И. Котков, Успенский сборник.., p. 305).

There are several issues in the Slavonic translation that should be addressed. First of all, it is the overall meaning of the phrase. According to John Chrysostom, the noise, the rich houses and the suburbs (where, supposedly, the wealthy citizens could retreat in their villas) are inherent to his city, but it is the people who are more praiseworthy ${ }^{21}$. However, the Slavonic translation suggests that this town has nothing but its people. The meaning is further adjusted by the vocabulary.

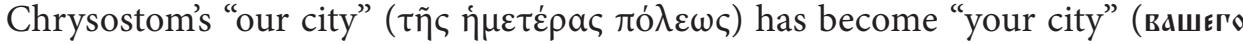

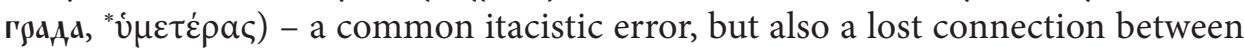
the preacher and the audience. The Slavonic Хл'Бвьци 'field, farm' hardly implied luxury ${ }^{22}$, and the big Roman house with many rooms, including the typical dining-room triclinium furnished with three couches, where the guests reclined for dinner, was rendered as долы н полаты, 'houses and palaces'.

The following passage refers undoubtedly to Antioch:

\footnotetext{
${ }^{20}$ Constantinople is well studied, see e.g. C. MANGo, Le développement urbain de Constantinople (IVe-VII siècles), Paris 1985; Byzantine Constantinople. Monuments, Topography and Everyday Life, ed. N. Necipoglu, Leiden 2001 [= MMe, 33]; P. Magdalino, Studies on the History and Topography of Byzantine Constantinople, Aldershot 2007.

${ }^{21}$ The reference to the suburbs in this homily was one of the reasons for it to be located in Antioch because of its famous suburb Daphne. However, W. Mayer questions the validity of this criterion

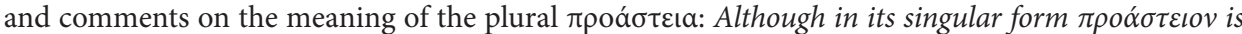
genuinely used by Chrysostom to indicate a physical suburb, it is possible that when the term appears in its plural form without a definite article, as in the instance adduced, it is being employed by him to describe not a physical area beyond the confines of the city but the dwellings or estates situated in those areas, W. MAYer, The Homilies of St John Chrysostom..., p. 389.

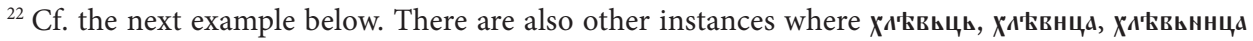

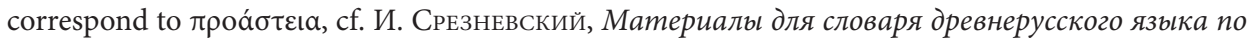
письменным памятникам, vol. III, Санкт-Петербург 1912, col. 1376.
} 


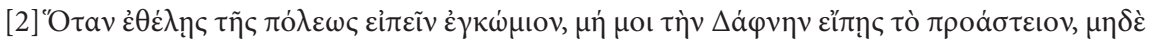

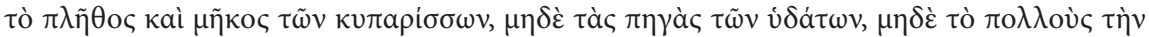

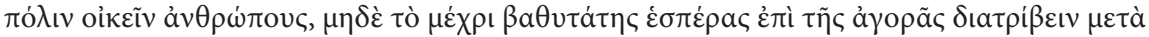

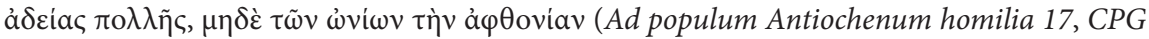
4330; $P G$, vol. XLIX, col. 179).

Whenever you want to praise the city, do not tell me about the suburb of Daphne, the multitude and magnitude of the cypresses, and the water fountains, nor that many people live in the city and one can walk around the agora deep into the night without any fear, nor about the abundance of goods.

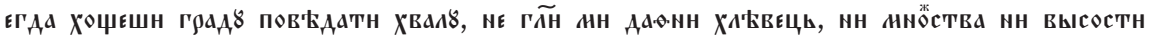

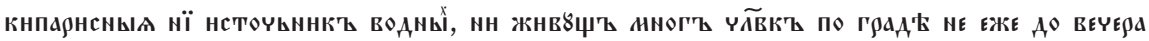

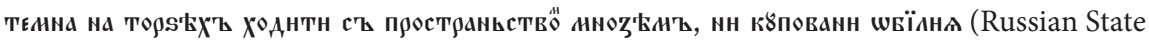
Library 304/I, No 151, 1597, f. 183v).

Unlike the first example, this translation is faithful and unadapted, including the mention of the Daphne suburb and the cypresses in Antioch. Since the entire homiletical series Ad populum Antiochenum is famously dedicated to this particular city and its people, it is not surprising that the references to the topography remained unchanged. In the translation, it constructs a "rhetorical" reality, which is consistent within its own context and is not necessarily connected to the surroundings of the Slavonic reader ${ }^{23}$. Another passage from the same homily also mentions the columns and stoas in the city and adds some information about the lexical variety of the translation:

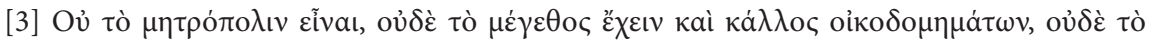

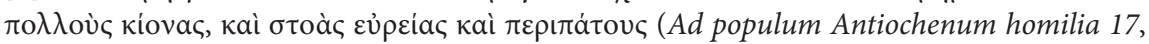
CPG 4330; $P G$, vol. XLIX, col. 176).

Not because it is a capital city, nor because of its big and beautiful buildings, numerous columns, broad colonnades and covered walks.

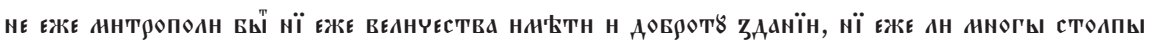
н прнкоылы н оүчнттелнїца (Russian State Library 304/I, No 151, 1597, f. 181r) ${ }^{24}$.

\footnotetext{
${ }^{23}$ Such a "constructed reality" is present not only in translation, but also in Chrysostom's original: The information that is supplied is largely allusive rather than specific. In addition, the way in which John refers collectively to "the baths", "the agora", and "the theatre" leads one to suspect that for pedagogical and polemical purposes he operates largely within a symbolic topography, W. MAYER, The Topography of Antioch..., p. 86.

${ }^{24}$ In the $15^{\text {th }}$-century translation (or revision, cf. note 15 above) of the homilies On the Statues, this

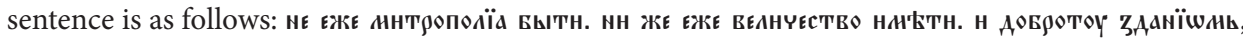
нн жє єжє аншбы стл'ыпы н пюнтворн на'Етн н ш̈водн (Vladislav the Grammarian's manuscript Rila

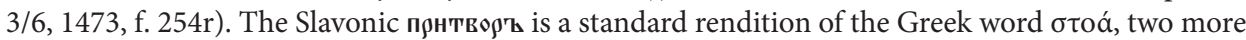

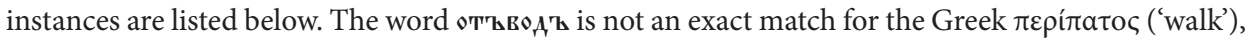
but is etymologically closer than the word оүчнтельннца in the example cited above.
} 
The translation in this example (especially прнкрылы н оүчнтєлнїца) does not

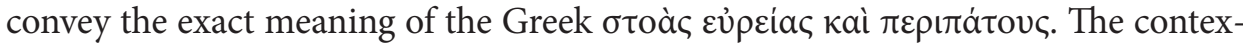
tual synonyms "columns", "colonnades" and "(covered) walks" allude to the famous covered streets in Antioch. The Slavonic оүчнтельннца 'school' is an unusual counterpart to $\pi \varepsilon \rho i ́ \pi \alpha \tau o \varsigma$ 'walk, place for walking. However, it corresponds to one of the secondary meanings of this word 'philosophical school'25 and reveals either a very well educated translator, or a random and inexplicable mistake.

The next two examples are from a Constantinopolitan homily, In sancto hieromartyre Phoca (CPG 4364). The selected passages are just a small sample of all the references to the imperial city. They describe the surroundings and refer to a particular event at the time of the delivery of the sermon:

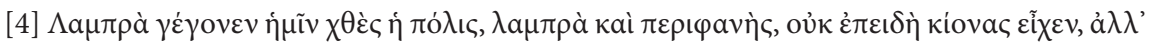

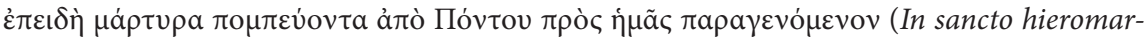
tyre Phoca, CPG 4364; PG, vol. L, col. 699).

The city was bright yesterday, bright and prominent, not because it has columns, but because of the martyr who came to us in a procession from the sea.

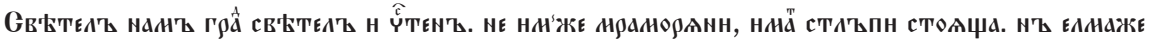

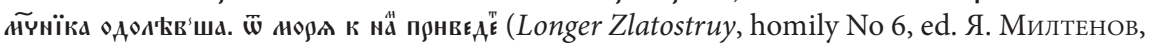
Златоструй..., p. 264).

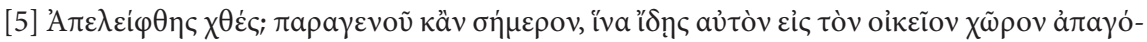

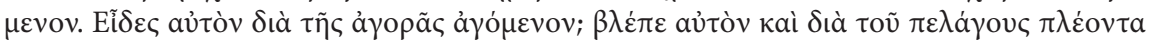
(In sancto hieromartyre Phoca, CPG 4364; PG, vol. L, col. 699).

Did you miss it yesterday? Then be here today and see him being brought back to his own place. Did you see how he was carried across the agora? Watch him cross the sea, as well.

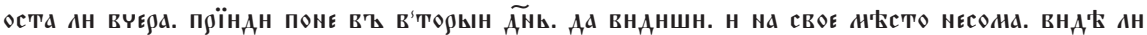

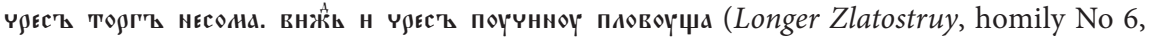
ed. Я. Милтенов, Златоструй..., p. 264).

Chrysostom's homily celebrates the two-day procession carrying the saint's relics through the city and across the sea - a single event, which connects the preacher and his audience with their shared actual reality ${ }^{26}$. To the Slavonic reader (and, indeed, to every member of an audience other than the one present at

${ }^{25}$ Cf. LSJ, p. 1382, s.v. $\pi \varepsilon \rho ı \pi \tau \varepsilon \dot{\varepsilon} \omega$ - one of the meanings is 'walk about while teaching, discourse' and

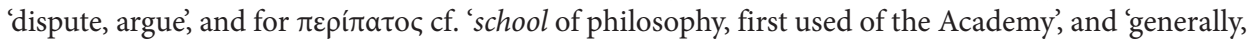
any school of philosophy'.

${ }^{26}$ On the date and provenance of the homily see Saint John Chrysostom, The Cult of the Saints. Select Homilies and Letters, praef. et trans. W. MaYer, B. NeIL, New York 2006, p. 75-76. 
the delivery of the sermon on this day in Constantinople) the deictic $\chi \theta \dot{\varepsilon} \varepsilon^{\prime}$ 'yesterday' was already anachronic, hence it was omitted in the translation of example 4 . The word вьчєяd in example 5, together with the sea and the "marble" columns of the city, create a new "rhetorical" reality, which includes also the images of other exempla, ecphraseis, and comparisons.

Chrysostom's cities were lively and dynamic, and their social and economic centres were the city squares and marketplaces, the agorai ${ }^{27}$. Chrysostom transfers the realistic image of the agora into the constructed reality of the rhetorical figures of speech. In the following exemplum he compares the troubled soul of an angry man to an agora and it is difficult to differentiate between the $4^{\text {th }}$-century reality and the topos. The description is very realistic, but its function in the text is purely rhetorical:

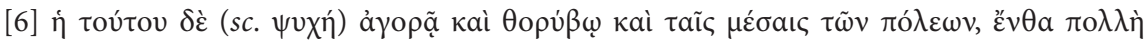

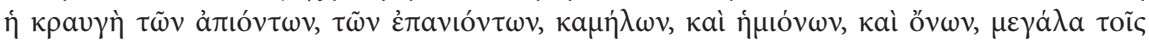

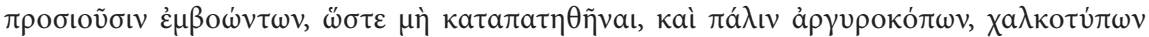

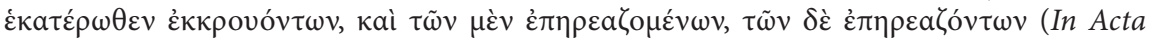
apostolorum homilia 6, CPG 4426; Oxford, New College No 75, p. 1432).

The soul of a troubled man] is similar to the clamour at the marketplace and the city streets, there is great noise from people coming and going, camels, mules, and donkeys, people shouting to the passers-by, so that they do not get trampled; and silversmiths and blacksmiths hammering from both sides; and people either bullying, or being bullied.

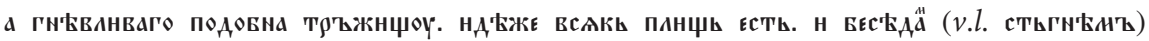

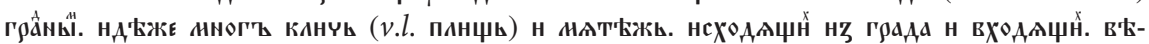

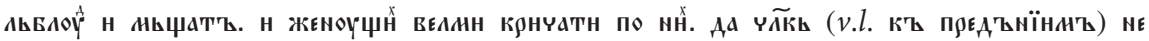

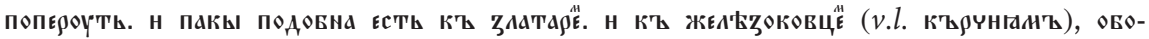

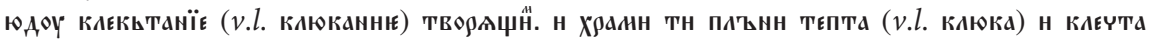

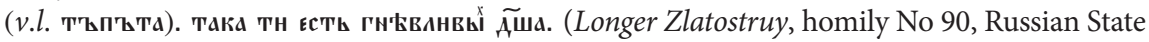
Library 173/I, No 43, f. $457 \mathrm{v}^{29}$ ).

\footnotetext{
${ }^{27}$ For his congregation, the main axes of life seem to be: the house, the agora, the baths and the church, see L.A. LAVAN, The Agorai of Antioch and Constantinople as seen by John Chrysostom, BICS 50, Issue Sup. 91, 2007, p. 157-167.

${ }^{28}$ The Old Church Slavonic translation is closer to the so called "rough" version, here cited after one of the oldest manuscript copies, Oxford, New College No $75\left(10^{\text {th }}-11^{\text {th }}\right.$ century). The text published

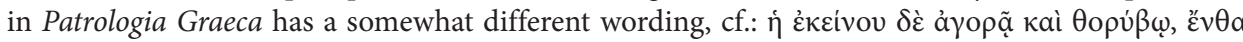

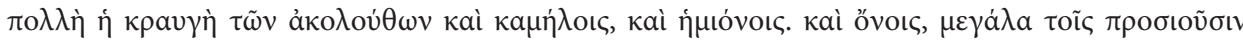

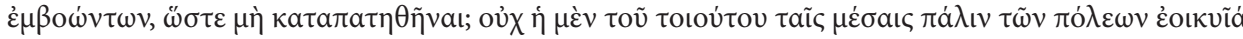

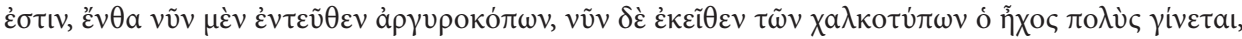

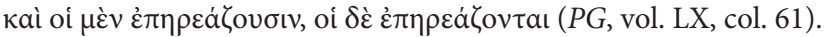

${ }^{29}$ The variants are after the so-called Shorter Zlatostruy, earliest copy Saint Petersburg, Russian National Library, F.п.I. 46 (Russian, $12^{\text {th }}$ century), edited in Т. ГеоргиевА, Златоструй om XII век, Силистра 2003.
} 
Whether the camels in the marketplace were real or imaginary for the Constantinopolitan audience, they were not part of the everyday life of the $10^{\text {th }}$-century Bulgarian translator (nor of the $15^{\text {th }}$-century Russian scribes and readers). However, any medieval audience could relate to the clamour and racket in the market (á)ора́, торъжнцв), the mules and their shouting owners on the streets

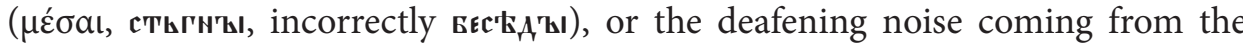
blacksmiths' workshops. Some variants of the words meaning 'noise' in the Slavonic manuscripts also suggest familiarity with the scene, which allows for a freer interpretation by the scribes.

\section{Private life and daily routine}

The urban environment and the public spaces were the scene where a large part of the citizens' daily life took place. This interaction between man and city is presented in the following several examples. In the evenings the narrow streets and squares were not the best place for the poor and the homeless:

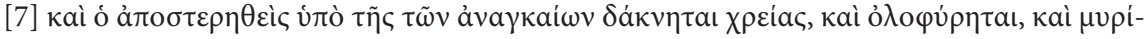

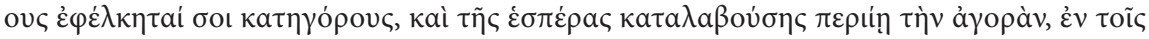

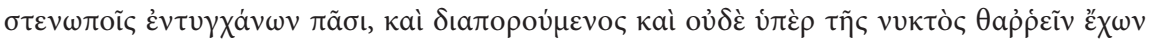
(In Epistulam primam ad Corinthios homilia 11, CPG 4428; PG, vol. LXI, col. 94).

And the deprived [by you] may be bitten by the most basic needs, and lament himself, and summon thousands of accusers upon you; and when the evening comes, he may go around the market-place, encountering all sorts of things in the alleys, and be at a loss, not daring to spend the night.

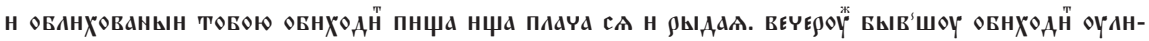

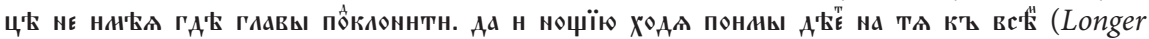
Zlatostruy, Homily No 74b, Russian State Library 173/I, No 43, f. 406r).

At the same time, the (wealthy) citizen in Chrysostom's reality, a member of his audience, visited the public baths in the evening before the late supper, after completing his daily chores in the agora:

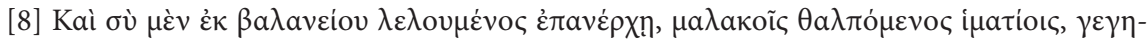

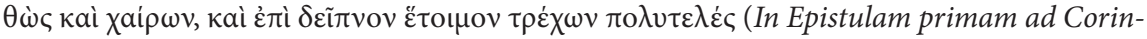
thios homilia 11, CPG 4428; PG, vol. LXI, col. 94).

And you come back refreshed after bathing, kept warm in soft garments, cheerful and happy, rushing to a lavish dinner. 


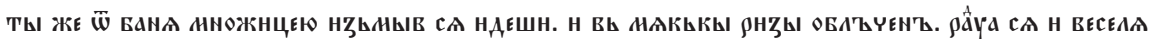
са на вєлнкоү вечєрюО Г९Адын (Longer Zlatostruy, Homily No 74b, Russian State Library 173/I, No 43, f. 406r).

The Slavonic translation in example 7 mentions only the dark and narrow

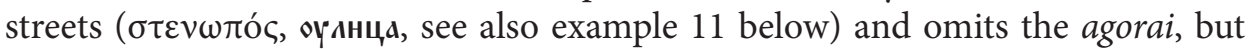
although it simplifies the wording of the original passage, it renders truthfully its general meaning. The next example 8 from the same episode is not adapted to the Slavonic audience and the translation keeps both the baths ( $\beta a \lambda \alpha v \varepsilon \tilde{I}_{\text {ov }}$ вaнra) and

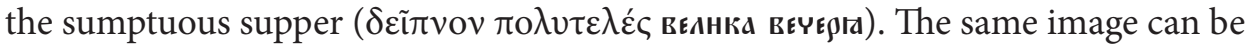
found also in other homilies ${ }^{30}$, e.g.:

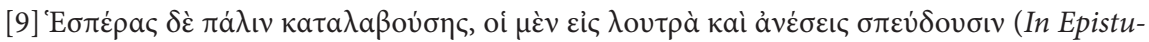
lam primam ad Timotheum homilia 14, CPG 4436; PG, vol. LXII, col. 577).

The evening comes again, and some are in a hurry to the public baths and relaxation.

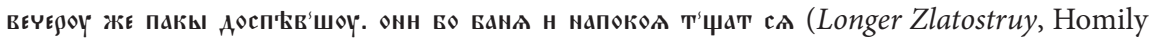
No 37, Russian State Library 173/I, No 43, f. 229r).

The Greek word $\delta \varepsilon i \pi \tau v o v$ from example 8 can denote any meal during the day, either lunch, dinner, or supper, but the context suggests that both going to the baths and the meal afterwards happen in the evening and the Slavonic translation reflects this accordingly. Examples 9 and 10 are unambiguous in this respect

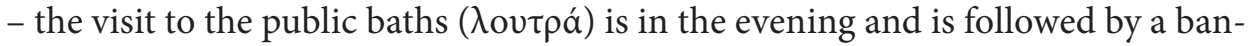
quet. This way of life was not accessible to all the citizens, cf. the continuation of example 9 below.

\section{The house}

The following examples depict domestic scenes in big Roman houses with servants and lavish banquets:

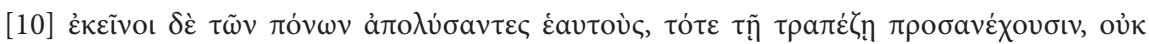

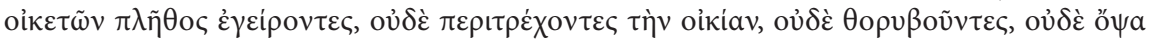

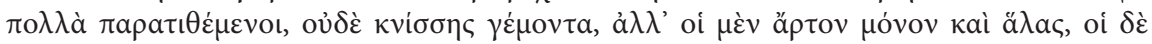

\footnotetext{
${ }^{30}$ Leslie Dossey's interesting study about the nightlife in the $4^{\text {th }}$-century big cities Antioch and Constantinople explores the shift of the main occupations of the citizens towards later hours (compared to the country and to earlier time-periods). Afternoon naps, baths, shopping and supper occur several hours later that before, cf. L. Dossey, Night in the Big City. Temporal Patterns in Antioch and Constantinople as Revealed by Chrysostom's Sermons, [in:] Revisioning John Chrysostom, ed. C.L. DE Wet, W. MAYer, Leiden-Boston 2019 [= CAEC, 1], p. 698-732.
} 


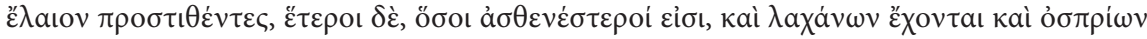
(In Epistulam primam ad Timotheum homilia 14, CPG 4436; PG, vol. LXII, col. 577).

The other ones attend to the table after finishing with their labour, without awakening a multitude of slaves, nor running around the house and raising a clamour, nor having many dishes full of meats, but some put on the table only bread and salt, others add olive-oil, and some - the weaker ones - have vegetables and beans.

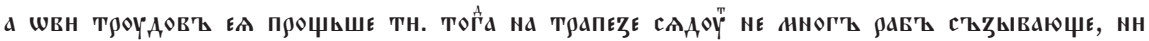

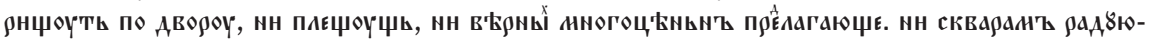

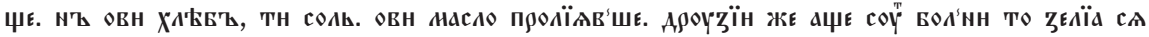
прїєнлюце н сочнва (Longer Zlatostruy, Homily No 37, Russian State Library 173/I, No 43, f. 229r).

This contrast between the wealthy citizens with their baths, big households

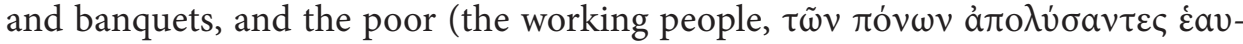

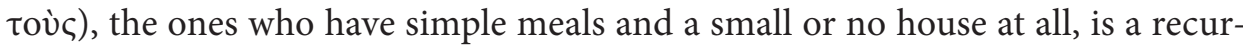
ring motif in Chrysostom's works:

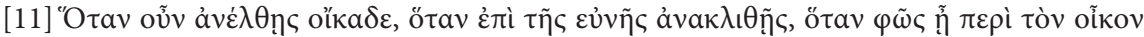

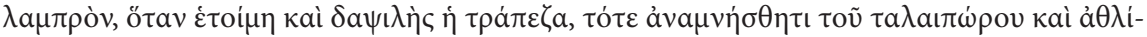

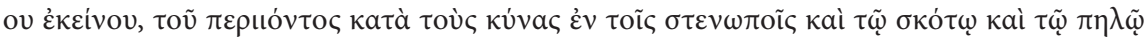
(In Epistulam primam ad Corinthios homilia 11, CPG 4428; PG, vol. LXI, col. 94).

When you come home, when you lay down on the couch, when the lights shine bright in the house, when the table is ready and full, then remember that miserable and unhappy one, walking down the alleys like a dog, in darkness and mud.

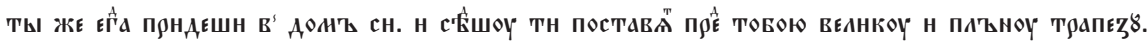

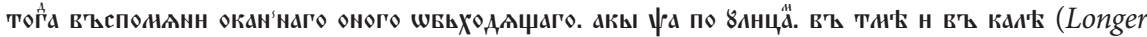
Zlatostruy, Homily No 74b, Russian State Library 173/I, No 43, f. 406r).

Example 11 presents a picture, where at least some streets or alleys (the same $\sigma \tau \varepsilon \nu \omega \pi$ oi from example 7) are dark and not paved. It also makes the transition from the public space into the residential area - into the dining-room of a Roman house. This is where the Slavonic translation shows some deviations and adaptations. The phrase "lights shining bright round the house" is omitted altogether (perhaps the medieval Bulgarian house was darker than its Byzantine counterpart, but this cannot be the only explanation of the omission). Chrysostom's

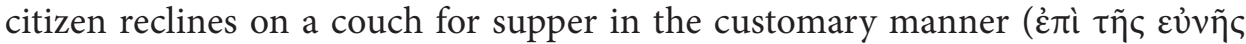
àvak $\left.\lambda_{1} \theta \tilde{n} \varsigma\right)$ - probably the couch in the triclinium from example 1, whereas the man in the constructed reality of the Slavonic translation sits down (c'kшoy TH) and someone else (a slave? a servant? a wife?) puts the table in front of him. The 
less fortunate men from example 10 are at the table in an unspecified position

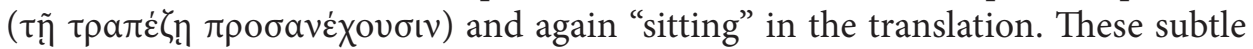
deviations of the translation suggest that the Slavonic audience did not differentiate between sitting at the table and reclining on the couch of a triclinium.

The next examples also give some architectural details, e.g. the following image of a Roman house:

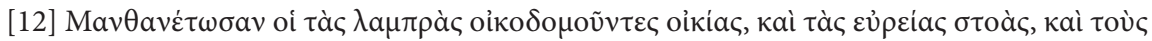

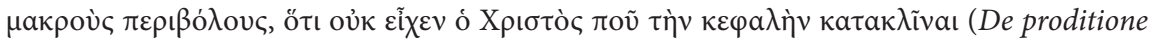
Iudae, $C P G$ 4336; $P G$, vol. XLIX, col. 378).

And those who build splendid houses and wide porticoes, and long courtyards, let them know that Christ did not have a place to rest his head.

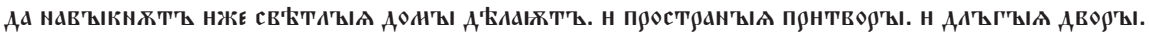

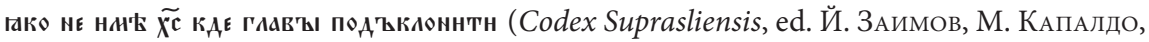
Супрасълски или Ретков сборник.., р. 416).

In cases like this one, the description of the house is a rhetorical device, but it mentions a colonnaded courtyard. The Slavonic word прнтворль, which is a com-

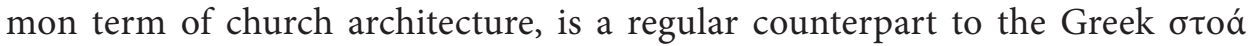
(cf. note 24 above). The next example does not give any architectural details, but the translation enhances the episode:

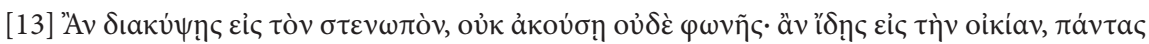

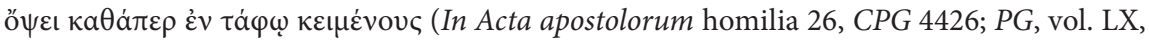
col. 202).

If you peek out to the street, you will not hear a sound; if you look into the house, you will see everybody lying as if in a tomb.

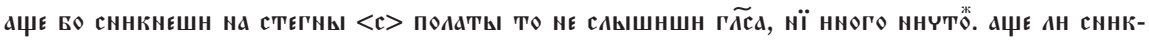

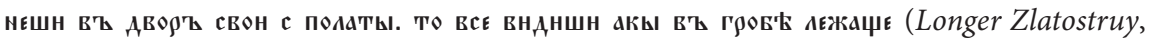
Homily No 41, Russian State Library 173/I, No 43, f. 256v).

The Greek sentence suggests that an observer is looking through the window out (towards the narrow street), and in (towards the house). In the Slavonic text the house is a palace (nолата) and the observer is looking out to the street,

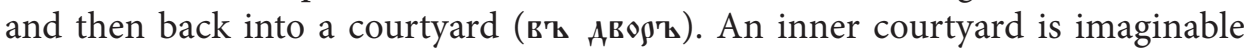
only in a big building - in the palace or in a monastery.

In the following description of the morning routine of a common citizen, a small alteration in the translation gives us an idea about the layout of the house: 


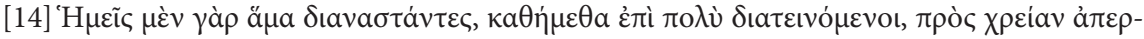

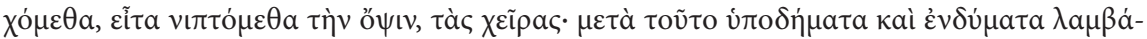

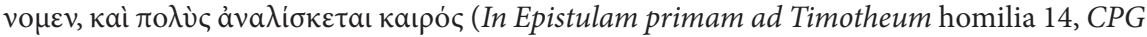
4436; PG, vol. LXII, col. 575).

As soon as we wake up, we sit up and stretch out, we answer the call of nature, then we wash our face and hands, afterwards we take our shoes and clothes, and a lot of time passes.

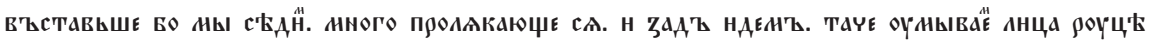

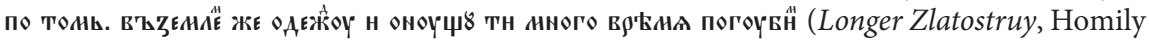
No 37, Russian State Library 173/I, No 43, f. 227v).

Early in the morning, after sitting up in the bed and stretching, and before

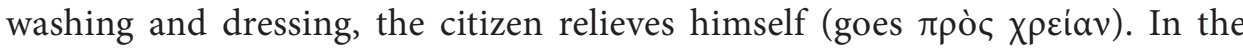

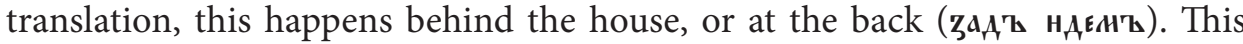
deviation in the Slavonic translation alludes to an area of the house, or outside the house, that is otherwise rarely mentioned. It is also another point of difference between the well-equipped Roman house and the average medieval Slavic houses.

The last example, which is another description of a building, also gives some interesting information about architectural terminology and adaptations of the source text:

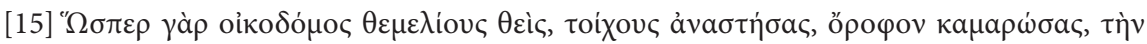

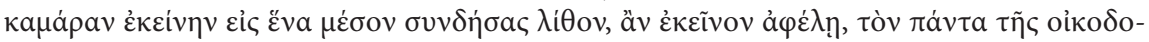

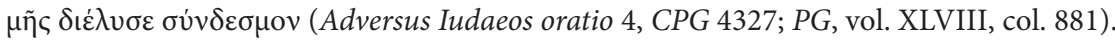

Just like the architect, who lays the foundations, builds the walls, furnishes the roof with a vault, and locks that vault with a single stone in the middle, if he takes away that stone, the whole structure of his building will collapse.

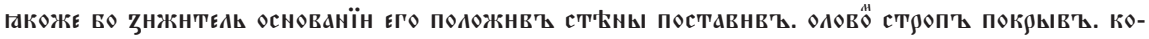

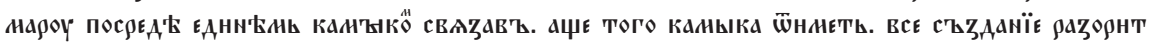
cA (Longer Zlatostruy, Homily No 8, Russian State Library 173/I, No 43, f. 76v).

The building in the Greek comparison has a vaulted roof built of stone, with a keystone on the top - a structure, characteristic not for a house, but for a church or a similar edifice. In the translation, it is covered with lead (оловӧ стлопт покрывъ $\mathbf{z}$ ) and there is also a stone on the top of the dome ${ }^{31}$. Other examples of

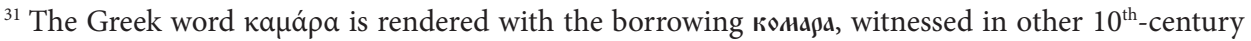
translations such as John the Exarch's Bogoslovie and Pseudo-Kaisarios' Erotapokrisis, see И. Сре3невский, Материальы для словаря..., vol. I, Санкт-Петербург 1893, col. 1263-1264 (s.v. комара); Я. Милтенов, Диалозите на Псевдо-Кесарий в славянската рбкописна традиция, София 2006 p. 544.
} 
the word lead $^{32}$. It seems that it was not unusual for a dome to be coated with lead, which suggests that the vault in this example was associated with a leaden church-dome - a notion which is not explicit in the Greek source.

Wide porticoes and long courtyards (cf. example 12) were not typical features of the medieval Bulgarian house, except for the ruler's palace. Even if we assume that the initial audience of the Old Church Slavonic translations was well familiar with the Byzantine culture, the topography of Constantinople, its squares, columns and obelisks, the surrounding sea etc. (cf. examples 4 and 5), the readers throughout the Slavic world in the following centuries most probably did not see villas with spacious courtyards, porticoes and a large body of water from their windows.

What did the $10^{\text {th }}$-century Bulgarian see from his window? Unlike Antioch and Constantinople, there is only limited archeological data about the medieval Bulgarian town and almost no information about the everyday life of the common citizen ${ }^{33}$. Pliska and Preslav, the two capitals of the First Bulgarian Kingdom $\left(7^{\text {th }}-11^{\text {th }}\right.$ century), had some monumental architecture, such as the ruler's palace ${ }^{34}$, churches, and city walls. However, the cities were in steady decline from the end of the $10^{\text {th }}$ century onwards and lost their significance in the Second Bulgarian Kingdom (12 $12^{\text {th }}-14^{\text {th }}$ century). According to the archeological and historical studies, the medieval Bulgarian fortified town had a residential area outside the city walls. Most people lived in small semi-dug-in houses ${ }^{35}$, the door opened directly to the street. In the later centuries the houses were made of stone and could have a backyard with service buildings. Some prominent citizens owned two-storey houses with many rooms. The marketplaces and the town-squares, formed from the intersection of two roads, were an important economic and social element

\footnotetext{
${ }^{32}$ Cf. И. СрезневскиЙ, Материалы для словаря..., vol. II, Санкт-Петербург 1902, col. 661, s.v.

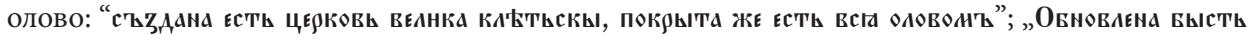

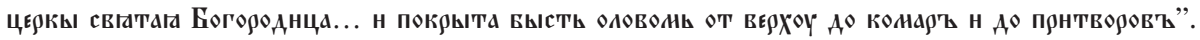

${ }^{33}$ The description of the medieval Bulgarian town is based on several general studies: К. Миятев, Архитектурата в средновековна България, София 1965; С. Лишев, Българският средновековен град. Обществено-икономически облик, София 1970; М. ХАРьовА, Укрепеният бблгарски средновековен град XIII-XIV в., София 1979; Д. Поливянни, Средновековният български град през XIII-XIV в. Очерии, София 1989; А. Миланова, Градът във византийска България (XIXII в.), [in:] Средновековен урбанизбм. Памет - Сакралност - Традииии, София 2007, p. 7-29; A. Aladzhov, The Byzantine Empire and the Establishment of the Early Medieval City in Bulgaria, [in:] Byzanz - das Römerreich im Mittelalter, vol. III, Peripherie und Nachbarschaft, ed. F. DAIM, J. DrauschKe, Mainz 2010, p. 113-158.

${ }^{34}$... since the palace covers a large area, its central part was taken by a courtyard enclosed by the balconies of the building, A. Aladzhov, The Byzantine Empire..., p. 120. This structure was probably burnt down at the beginning of the $9^{\text {th }}$ century.

${ }^{35}$ Ibidem, p. 116.
} 
of the medieval town. There is no information about city lights, but there were baths and a sewage system in the First Bulgarian kingdom ${ }^{36}$ at least at the palace. In the $13^{\text {th }}-14^{\text {th }}$ century the water supply was provided by cisterns and wells ${ }^{37}$.

The medieval Bulgarian town shared some features with the Byzantine major cities and differed in others. From the examples above, and the entire history of translation, transmission, and reception of Byzantine texts in the medieval Slavonic literature, it is evident that the homilies of John Chrysostom had many points of reference to the actual reality of $4^{\text {th }}$-century Antioch and Constantinople that were not present to the Slavonic audience. The translators of Chrysostom's homilies, however, did not adapt each detail that might be unfamiliar. Many realia are unchanged in the translation - there are exact renditions of stoas, columns, baths, vaulted roofs and camels in the agora, athletic games and theatrical performances (not included in this study), etc. At the same time, some passages were slightly adapted without damaging the general meaning, e.g. the villas with triclinia in the suburbs, where people dined lying on couches, became "fields" and "palaces" (example 1), and the master sat at the table for dinner (example 11).

Urban images were transferred from the Byzantine world into medieval Bulgaria also in other literary genres, such as the juridical literature. One of the law texts translated from Greek into Old Church Slavonic pertains to the same topic - life in the city - and uses vocabulary similar to the examples commented above. This text is the Procheiros nomos - a Byzantine juridical compendium based on Justinian's law ${ }^{38}$. Title 38 of the Procheiros nomos deals specifically with the urban environment, buildings and renovations, private and public property, relationships between neighbours, co-ownership, etc. The Slavonic translation (the earliest witness is from the $13^{\text {th }}$ century) contains numerous technical terms which are a significant contribution to the terminological vocabulary of the Slavonic language. This text deserves special attention, but here I will briefly comment on some issues which are relevant to the present study.

The Procheiros nomos settles legal matters in the Eastern Roman Empire which are irrelevant to the medieval Bulgarian, Serbian, or Russian reality. For instance, the cases in chapters 14 and 18 involve multistorey residence buildings, which were not typical for the medieval Bulgarian town (upper floors should not be heavier than the ground-floor can support, and the residents of the groundfloor may not conduct smoke into the homes of their neighbours above). Other

\footnotetext{
${ }^{36}$ Ibidem, p. 118.

${ }^{37}$ Д. Поливянни, Средновековният български град..., p. 134-135.

${ }^{38}$ A lexical study and an edition of the Slavonic translation of title 38, with additional bibliography, see in: М. ЦиБРАнсКА-КостовА, Градският закон и градското благоустройство в южнославянски контекст, СЛ 57-58, 2018, p. 163-193. The Greek text is available in: J. Zepos, P. Zepos, Prochiron, [in:] Jus Graecoromanum, vol. II, Leges imperatorum Isaurorum et Macedonum, Aalen 1962, p. 114-228. The numbers of the chapters below follow the segmentation in the Slavonic translation.
} 
chapters deal with topography and landscaping characteristic to the Mediterranean - according to chapters 5 and 6 , the residents have the right to preserve

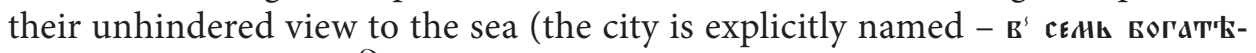
ни Г $\rho а д \mathbf{A}$ '. Chapters 23-24, 37, 51, 58 deal with developed sewage and water systems, and chap-

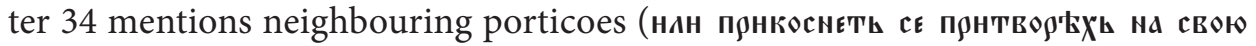

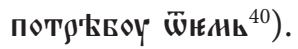

These big-city problems were translated into Slavonic without significant adaptation. Apart from several explanatory additions, the translation follows faithfully its Greek source. This lack of adjustment is an indication that the technical juridical text was perceived not as a legal manual, but as literature ${ }^{41}$. The connections to the actual reality in the original were lost in the new context of the translation in a way that is similar to the transformation of the oral sermon into a written literary genre.

The more a text is used and appropriated, the more it is subjected to alterations. The translations of John Chrysostom's homilies show both tendencies - in some cases they are true to the Greek source, in others they are adapted to the new audience. The examples cited above were translated by different anonymous translators in the early $10^{\text {th }}$-century Bulgaria, they represent various approaches towards the original. The genre of the homily is also an important factor in this process. Although the written homily is removed from the initial moment of delivery, it lives on as reading matter or material for new sermons. John Chrysostom's urban images are only a small piece of the cultural and literary history. They were often documents of his time, pictures of his fellow-citizens and their surroundings, which served sometimes as rhetorical means for conveying a deeper and more general message. For the Slavonic audience, however, these episodes were equal to all the other figures of speech - parables, exempla, etc., which were one step further from their day-to-day life. Most of this literature was monastic, for individual or collective reading in monasteries, but sometimes also for highly educated and prepared readers (we still do not know enough about the reception of these texts). Therefore, the translation of the realia into Old Church Slavonic involved not only adaptation in order to make the foreign reality more relatable, but it was also a transformation of a document into literature.

\footnotetext{
${ }^{39}$ М. ЦиБРАнсКА-КостовА, Градският закон..., р. 187.

${ }^{40}$ Ibidem, p. 190, in the Greek text otoá, cf. J. Zepos, P. Zepos, Prochiron..., p. 211. For the same Slavonic word прнтворт cf. examples 3 and 12 and notes 24 and 32 above.

${ }^{41}$ D. Naydenova argues that the early translations of various Byzantine legal texts into Old Church Slavonic were part of the political ideology rather than a state legislation, and they should be considered literary sources, cf.: D. NAYDenova, Cyrillo-Methodian Legal Heritage and Political Ideology in the Mediaeval Slavic States, PBAS.HSS 1.1, 2014, p. 3-16.
} 


\section{Bibliography}

Aladzhov A., The Byzantine Empire and the Establishment of the Early Medieval City in Bulgaria, [in:] Byzanz - das Römerreich im Mittelalter, vol. III, Peripherie und Nachbarschaft, ed. F. DAIM, J. Drauschke, Mainz 2010, p. 113-158.

Ameringer T., The Stylistic Influence of the Second Sophistic on the Panegyrical Sermons of St. John Chrysostom. A Study in Greek Rhetoric, Washington 1921 [= Patristic Studies, 5].

Bulanin D., Tekstologičeskie i bibliografičeskie arabeski. Priloženie V. Andrianty v staršem slavjanskom perevode, [in:] Katalog pamjatnikov drevnerusskoj pis'mennosti 11-14vv., Sankt-Peterburg 2014, p. 489-510.

Burns M.A., Saint John Chrysostom's Homilies on the Statues. A Study of Their Rhetorical Qualities and Form, Washington 1930 [= Patristic Studies, 22].

Byzantine Constantinople. Monuments, Topography and Everyday Life, ed. N. NeCIPOGLU, Leiden 2001 [= The Medieval Mediterranean, 33].

Dossey L., Night in the Big City. Temporal Patterns in Antioch and Constantinople as Revealed by Chrysostom's Sermons, [in:] Revisioning John Chrysostom, ed. C.L. DE WET, W. MAYER, LeidenBoston 2019 [= Critical Approaches to Early Christianity, 1], p. 698-732, https://doi.org/10.1163/ 9789004390041_022

Georgieva T., Zlatostruj ot XII vek, Silistra 2003.

HARBova M., Ukrepenijat bălgarski srednovekoven grad 13-14 v., Sofija 1979.

IlARIj IEROM., ArSEnij IEROM., Opisanie slavjanskih rukopisej biblioteki Svjato-Troickoj Sergievoj lavry, Moskva 1878.

Ilieva T., Antičnata kultura prez prizmata na srednovekovnija bălgarski knižoven ezik, Dzjalo 10, 2017, http://www.abcdar.com/magazine/X/T.Ilieva_1314-9067_X.pdf

Lavan L.A., The Agorai of Antioch and Constantinople as Seen by John Chrysostom, "Bulletin of the Institute of Classical Studies" 50, Issue Sup. 91, 2007, p. 157-167, https://doi.org/10.1111/ j.2041-5370.2007.tb02386.x

LEONID ARHIM., Svedenie o slavjanskih rukopisjah, postupivših iz knigohranilišča Svjato-Troickoj Sergievoj lavry v biblioteku Troickoj duhovnoj seminarii v 1747 g. (nyne nahodjaščihsja v biblioteke Moskovskoj duhovnoj akademii), Vyp. 2, Moskva 1887.

Liddell H.G., Scott R., Jones H.S. et al., A Greek-English Lexicon, ${ }^{9}$ Oxford 1996.

LIŠEv S., Bălgarskijat srednovekoven grad. Obštestveno-ikonomičeski oblik, Sofija 1970.

Magdalino P., Studies on the History and Topography of Byzantine Constantinople, Aldershot 2007.

MANGo C., Le développement urbain de Constantinople (IV -VII siècles), Paris 1985.

MaYer W., The Homilies of St John Chrysostom. Provenance. Reshaping the Foundations, Rome 2005.

Mayer W., John Chrysostom: Extraordinary Preacher, Ordinary Audience, [in:] Preacher and Audience. Studies in Early Christian and Byzantine Homiletics, ed. P. Allen, M. Cunningham, Leiden 1998, https://doi.org/10.1163/9789004391666_007

Mayer W., The Topography of Antioch Described in the Writings of John Chrysostom, [in:] Les sources de l'histoire du paysage urbain d'Antioche sur l'Oronte. Actes des journées d'études des 20 et 21 septembre 2010. Colloques de l'université Paris 8, ed. C. Saliou, Paris 2012, p. 81-100.

Menander Rhetor, ed. et trans. D.A. RusseLL, N.G. WiLson, Oxford 1981.

Mihanović Homiliar, ed. R. AitzetmüLler, Graz 1957. 
Mijatev K., Arhitekturata v srednovekovna Bălgarija, Sofija 1965.

Milanova A., Gradăt văv vizantijska Bălgarija (11-12 v.), [in:] Srednovekoven urbanizăm. Pamet - Sakralnost - Tradicii, Sofija 2007, p. 7-29.

Miltenov Y., Dialozite na Psevdo-Kesarij v slavjanskata răkopisna tradicija, Sofija 2006.

MiLtenov Y., Zlatostruj: starobălgarski homiletičen svod, săzdaden po iniciativa na bălgarskija car Simeon. Tekstologičesko i izvorovedsko izsledvane, Sofija 2013.

MirČEva E., Germanov sbornik ot 1358/1359 g. Izsledvane i izdanie na teksta, Sofija 2006.

Mušinskaja M.S., Adrianty Ioanna Zlatousta v južnoslavjanskih i russkih pamjatnikah, [in:] Lingvističeskoe istočnikovedenie i istorija russkogo jazyka (2002-2003), Moskva 2003, p. 27-74, http://www.ruslang.ru/istochnik_2003

Naydenova D., Cyrillo-Methodian Legal Heritage and Political Ideology in the Mediaeval Slavic States, "Papers of BAS. Humanities and Social Sciences" 1.1, 2014, p. 3-16.

Polivjanni D., Srednovekovnijat bălgarski grad prez 13-14 v. Očerci, Sofija 1989.

Popovski J., Thomson F.J., Veder W.R., The Troickij Sbornik (Cod. Moskva, GBL, F.304 (Troice-Sergieva Lavra) N 12). Text in Transcription, "Полата книгописная / Polata Knigopisnaja" 21-22, 1988.

Preacher and Audience. Studies in Early Christian and Byzantine Homiletics, ed. P. Allen, M. CunNINGHAM, Leiden 1998.

Saint John Chrysostom, The Cult of the Saints. Select Homilies and Letters, praef. et trans. W. MaYER, B. NeIL, New York 2006.

The Sermon, ed. B.M. KienzLE, Turnhout 2000.

Simeonov sbornik (po Svetoslavovija prepis ot 1073 g.), vol. I, Izsledvanija i tekst, Sofija 1991; vol. II, Rečnik-indeks, Sofija 1993; vol. III, Grăcki izvori, Sofija 2015.

SLAVova T., Vizantijski realii v prevodačeskata praktika na starobălgarskite knižovnici, [in:] Laudator temporis acti. Studia in memoriam Ioannis A. Božilov, vol. II, Ius, imperium, potestas litterae ars et archaeologia, ed. I.A. Biliarsky, Sofia 2018, p. 242-253.

SREZnevskij I., Materialy dlja slovarja drevnerusskogo jazyka po pis'mennym pamjatnikam, vol. I, Sankt-Peterburg 1893; vol. II, Sankt-Peterburg 1902; vol. III, Sankt-Peterburg 1912.

Suprasălski ili Retkov sbornik, vol. I-II, ed. J. ZAimov, M. KAPALDo, Sofija 1982.

Tотомаnova A.-M., Svedenijata za grăko-rimskija svjat v slavjanskija ekscerpt ot Hronikata na Julij Afrikan. Problemi na recepcijata, [in:] POLYISTŌR. Scripta slavica Mario Capaldo dicata, ed. K. DidDi, Moskva 2015, p. 316-327.

Tsibranska-Kostova M., Gradskijat zakon i gradskoto blagoustrojstvo v južnoslavjanski kontekst, “Старобългарска литература" / "Starobălgarska literatura" 57-58, 2018, p. 163-193.

Turilov A.A., Andrianty, [in:] Pravoslavnaja ènciklopedija, vol. II, Moskva 2001, p. 410, http://www. pravenc.ru/text/115376.html

Uspenskij sbornik 12-13vv., ed. S.I. Kоткоv, Moskva 1971.

VoIcu S., Pseudo-Giovanni Crisostomo: i confini del corpus, "Jahrbuch für Antike und Christentum" 39, 1996, p. 105-115.

VoIcu S., Une nomenclature pour les anonymes du corpus pseudo-chrysostomien, "Byzantion. Revue internationale des études byzantines" 51, 1981, 297-305.

Zepos J., Zepos P., Prochiron, [in:] Jus Graecoromanum, vol. II, Leges imperatorum Isaurorum et Macedonum, Aalen 1962, p. 114-228. 


\begin{abstract}
John Chrysostom was not only one of the most prolific and influential authors of late antiquity but also a renown preacher, exegete, and public figure. His homilies and sermons combined the classical rhetorical craft with some vivid imagery from everyday life. He used descriptions, comparisons, and metaphors that were both a rhetorical device and a reference to the real world familiar to his audience. From $9^{\text {th }}$ century onwards, many of Chrysostom's works were translated into Old Church Slavonic and were widely used for either private or communal reading. Even if they had lost the spontaneity of the oral performance, they still preserved the references to the $4^{\text {th }}$-century City, to the streets and the homes in a distant world, transferred into the $10^{\text {th }}$-century Bulgaria and beyond. The article examines how some of these urban images were translated and sometimes adapted to the medieval Slavonic audience, how the realia and the figures of speech were rendered into the Slavonic language and culture. It is a survey on the reception of the oral sermon put into writing, and at the same time, it is a glimpse into the late antique everyday life in the Eastern Mediterranean.
\end{abstract}

Keywords: John Chrysostom, literary reception, translations into Old Church Slavonic, urban life, Antioch, Constantinople

Aneta Dimitrova

Sofia University “St. Kliment Ohridski” Department of Cyrillo-Methodian Studies

15 Tsar Osvoboditel Blvd.

1504 Sofia, Bulgaria

anetagd@uni-sofia.bg 